\title{
APPROACHES TO ACTIVE LABOUR MARKET POLICY IN THE SLOVAK REPUBLIC, CZECH REPUBLIC AND IN FINLAND
}

The subject matter of the article consists in the issue of unemployment, which is the problem in many countries. The article describes approaches to the solution of the unemployment from the point of view of several economic specializations in theory. Active labour-market policies have developed significantly over the past two decades across Organization for Economic Cooperation and Development (OECD). This article describes the approaches to the solution of unemployment problem of the Czech Republic, Slovak Republic and Finland. Objective of this article is to account variant of active labour market policy.

Keywords: Unemployment, active labour market policy, employment.

\section{Introduction}

Employment enhancement is one of many targets in all countries. The subject matter of article consists in comparing the approaches to the active labour market policy in the Slovak Republic, in the Czech Republic and in Finland. The current economic crisis aggravates this situation. Enterprises dismiss many employees and keep only the key and strategic staff, or they seek only highly skilled workforce. As the numbers of job seekers are high, only the best of them get employed.

The aim of the article is to describe the differences of employment policies despite the fact that many European studies point out at the ambiguous relationship between the active measures and unemployment. The contribution of active policy consists in the proactive approach to the labour market. The passive policy used so far has aimed at providing financial benefit and protecting its recipients from poverty [1]. Active Labour Market Policies - including measures such as job search assistance, labour market training, wage subsidies to the private sector, and direct job creation in the public sector - are an important element of European countries' effort to combat unemployment.

\section{Institutional framework of the labour market}

Active labour market policies (ALMP) are only part of the institutional framework. According to the following aspects of the labour market can be distinguished:
- legal protection of employment,

- structure of wage negotiation,

- active labour market policy,

- tax burden on labour,

- social benefits system within the course of unemployment.

The action of the previous aspects can be seen from two points of view:

- State interventions by means of these institutional aspects and their common functioning is called market regulation;

- The labour market can be viewed in terms of flexibility and we thus look for an optimum for effective functioning of the economy [2].

There are several reasons why states carry out interventions in the labour market. The main reason consists in the injustice in the labour market and market failures. In the report of the World Bank Report 1995 [3] four basic reasons for intervention were published:

- disbalanced market power - workers can see ourselves in a weak position for negotiating, which may cause an increased interest in their protection,

- discrimination - disadvantaged groups (on the ground of gender, age...) experience discrimination on the labour market,

- imperfect information - the particular actors do not always dispose of complete information to make high quality decisions,

\footnotetext{
* ${ }^{1}$ Lubica Konusikova, ${ }^{2}$ Alzbeta Kucharcikova

${ }^{1}$ Silesian university in Opava, School of Business Administration in Karvina, Czech Republic

${ }^{2}$ Department of Macro and Microeconomics, Faculty of Management Science and Informatics, University of Zilina, Slovakia

E-mail: konusikova.lubica@gmail.com
} 
- inadequate insurance against risk - the inability of workers to insure against the risks such as unemployment and disability.

Active labour market policy brings many effects on unemployment. Some of the effects are intended in advance and have become the reason for the creation of the tools of active labour market policies, but there are as well effects which were not foreseen in advance.

The positive effects have been identified by Calmfors [ 4 and 5]:

- The effect on the process of job seeking - the aim of the consulting activity provided by the state and addressed to the unemployed is to streamline this process. It means to increase the number of successful candidates applying for one vacancy. This effect is usually referred to as the primary objective of active labour market policy.

- The effect on competition among working positions - because any candidate who has completed a retraining program, can become significantly more attractive for employers.

- The effect on the allocation of labour among the particular sectors in the economy - via ALMP, the possibility of promoting the labour force transfer from a stagnating sector into a prospering sector with better productivity.

Layard [6] also identified the positive:

- efficiency - more efficient job search process by means of skills improvement through retraining courses,

- productivity - active labour market policy can increase labour productivity as a result of re-training or learning directly at the workplace,

- competitiveness - more competition in the process of job seeking,

- usefulness - active labour market policy reduces the uselessness of the unemployed as it provides work to the job seekers facing problems to enter the labour market.

Naturally, in the process of the application of active labour market policies, some unintended negative impacts arise and reduce the effects of active labour market policy. Sirovatka et al. [7] mentioned some of them:

- Lock in effect - the participants of the active policy programs have less time to search for a vacancy, or postpone job seeking for later. This effect tends instead to shift the employment and wage-setting schedules to the left. The consequence is then a tendency to lower regular employment (whereas the impact on the real wage is still unclear). Whether or not the treatment effect dominates the locking-in effect is an empirical issue [8].

- Creaming off - stands for the preference for the job seekers in need of a job at the expense of the more competent job seekers in the process of placement into programs of active labour market policy. The purpose consists in the achievement of better gross results of individual programs.
Fraser [9] presented a different view on the effect of decreasing efficiency of the labour market active policy:

- Deadweight effect - this effect means that a part of the candidates would be hired despite of their non-participation in the program of active labour market policy.

- Substitution effect - this effect means that the subsidized employees receive an occupation at the expense of those benefiting neither from a subsidized work place nor incorporation in the program of ALMP.

- Expelling effect - companies receiving a wage subsidy thus gain an advantage over the other companies as they can increase their market share on the market.

Many studies confirm that the evaluation of active policies is ambiguous. At its high diversity, the active policy does not have a strong chance to reduce the total employment rate on the labour market. There exist many different interpretations of the concept of active labour market policy. "Here I shall use a narrow definition: measures in order to improve the functioning of the labour market that are directed towards the unemployed" [10].

The active policy is a relatively recent topic for the Slovak Republic. Upon the accession of the Slovak Republic to the EU, there have come alterations in legislation, which are involved in the Act on Employment Services No. 5/2004 Coll.

\section{Active labour market programmes}

A large variety of different ALMP programs exist among EU member states and other European countries. It is possible to classify these programs into a set of six core categories. These categories are very similar to the corresponding classifications that have been suggested and used by the OECD [11] and Eurostat [12].

Training - encompasses measures like classroom training, on-the-job training and work experience. The measures can either provide a more general education (such as e.g. language courses, basic computer courses or other basic courses) or specific vocational skills (e.g. advanced computer courses or courses providing e.g. technical and manufacture skills). Training programs constitute the classic measures of active labour market policy.

Private sector incentive programmes - the main goal of this setting is to encourage employers to hire new workers or to maintain jobs that would otherwise be broken up. These subsidies can either be direct wage subsidies to employers or financial incentives to workers for a limited period of time. Another type of subsidized private sector employment is self-employment grants: Unemployed individuals who start their own business will receive these grants.

Direct employment programmes in the public sector - focus on the provision of public works or other activities that produce 
public goods. These measures are mainly targeted at the most disadvantaged people. It s important to keep people in contact with the labour market. Service - this tool includes job search assistance. It should serve to increase the efficiency in searching for new employment.

Programs for young unemployed - this group includes primarily various training programmes, wage subsidies and other financial contributions.

Measures for the disabled - a group of people for whom the various contributions are necessary in order to enter the labour market. These measures are designed for employers, but also for individuals, for example in the form of wage subsidies.

\subsection{Active labour market policy}

The primary role of active labour market policy consists in facilitating and accelerating the transition to paid work as well as in using special programs in order to maintain people's ability to work with the aim of finding a permanent place on the labour market. [13] Active labour market policy represents a younger form of labour market policy, which arose as a reason of unsuitable passive policy, since the passive policy gradually became a disincentive to job seekers. The services presented by the active labour market policy have varied in nature while their main objective nowadays is to motivate people to seek work [14].

\section{Slovakia}

The active policy (by means of the so called active measures on the labour market) is solved by the Act on Employment Services No. 5/2004 as amended. This legislation came into force in February 2004 and was abolished by the Act No. 387/1996 Coll. on Employment.

The Act underwent several changes in 2004, the changes have affected several areas including labour market policy and employment enhancement. According to the Office of Labour, Social Affairs and Family of the Slovak Republic, the particular instruments of Active labour market policy are categorised as follows [8]:

1) instruments and contributions increasing employability,

2) instruments and contributions increasing employment,

3) instruments and contributions supporting the sustainability of existing jobs.

ad 1) Instruments and contributions increasing employability:

- Reimbursement of travel expenses - related to the participation in a job interview or recruitment process held by an employer or to the participation in a group recruitment process organized by the labour office ( $\$ 32$ Article 12 letter D).

- Contribution to graduate practice (\$32 Article 12 letter D).
- Contribution to activation performance in the form of minor municipal services provided to the community or in the form of minor services for the self-governing region (\$ 52).

- Activation allowance in the form of voluntary service (§ 52a).

ad 2) Instruments and contributions increasing employment:

- Contribution to self-employment (\$ 49).

- Contribution to employment of disadvantaged jobseekers (\$50).

- Contribution to support regional and local employment (\$50j).

- Contribution to create sheltered workplaces (\$56).

- Contribution to persons with disabilities to operate or perform self-employment (§ 57).

ad 3) Instruments and contributions supporting the sustainability of existing jobs

- Education and training of an employee for the labour market (§ 47).

- Contribution supporting vacancies sustainability (\$50k).

- Contribution supporting commuting to work (§ 53).

- Contribution supporting moving in order to work (\$ $53 a$ ).

- Contribution for transportation to work (\$53b).

- Contribution to keep a disabled person in the particular occupation (\$ 56a).

- Contribution to provide a work assistant (\$ 59).

- Contribution to cover the running costs of sheltered workshops or sheltered workplace and travel expenses for employees (§60).

Information, advisory and specialized services - in accordance with the Act No. 5/2004 Coll. on Employment services

- Information and advisory services for career choice provide information and specialized advice on the types of occupations and the corresponding requirements.

- Information and advisory services for the choice of employment - information and specialized advice in the areas of: health requirements, technical skills and practical experience related to the vacancy is provided.

- Information and advisory services for an employee selection provide employers with information in the process of selecting a suitable employee for the corresponding occupation.

- Information and advisory services in the process of employee adaptation to the new occupation - this information facilitates the adaptation process of a new employee.

The authorised office free of charge provides information and advisory services. However, such services can be provided also by a natural or a legal entity performing activities in accordance with the Act on Employment Services.

\section{Czech Republic}

The instruments of the active labour market policy contribute to the assurance of full employment and to the process of new vacancies creation. On the ground of the sources available in the 
Ministry of Labour and Social Affairs, the instruments used in the Czech Republic involve the following [15]:

- Retraining - is realized upon the agreement between the particular Labour Office and a jobseeker. The Regional Office performs retraining on the ground of the jobseeker's reference. An employer upon an agreement with the labour office can realize the retraining also.

- Investment stimuli - stands for a tangible support for the creation of new vacancies and for retraining their employees. The stimuli are legislatively defined by the Act No. 72/2000 Coll. The stimuli are granted to natural or legal entity provided that the entity meets the general requirements defined by the law on investment stimuli.

- Community service - this instrument is a time-limited employment opportunity for a worker difficult to be placed on the labour market for long time, the community service can be performed only for the period shorter than 12 consecutive months. These vacancies are generated upon an agreement of the employer and the respective Labour Office. In the process of the vacancy creation, the employers can be reimbursed payroll costs including the expenses for social and health insurance. Community services are mainly related to the activities beneficial for communities - cleaning of buildings and their surroundings.

- Socially integrated jobs - the objective of this contribution is the establishment of vacancies or location of particular applicants unable to be employed in a different way. The contribution shall be granted for the maximum period of 12 months,

- Contribution for training - the contribution is provided to an employer who creates a vacancy and employs a job seeker requiring more care (Section 33 of the Act on Employment). The contribution is paid for the maximum period of three months and may not exceed a half of the minimum monthly salary.

- Contribution in the transition to a new business program - is designed for employers switching to a new production program and thus cannot provide their employees with the work within the specified range during their working hours. The transition to a new business program is a change relating to business changes and is registered in the Commercial Register, or it can be a major technological change in the business. This contribution is paid for a period of six months as a partial payment of salary compensation.

- Sheltered workshops - are defined as an established work place occupied by at least $60 \%$ of employees with disabilities, while the workplace was established upon an agreement with the Labour Office. The sheltered workshops set up under this agreement shall be adapted to the disability of employees, for example by providing wheelchair access.

Protected workplace - is defined as a place established by an employer for people with disabilities. It arises in the same process as the others, on the ground of an agreement with the Labour Office. The agreement is usually concluded for the period of three years. The agreement may be also concluded with a disabled person who is self-employed

\section{Finland}

The labour market policy in Finland gives the importance on the labour market training measures. The finnish labour market policy is based on a broad selection of services. The other major programmes are the employment subsidies and direct job creation. Finland and at the same time the Slovak Republic experienced a very deep depression in the early 1990s [16]. In the late 1990s and early 2000 there were some reforms of labour market. These reforms concentrated on public employment service. The PES reforms contain regular interviews, skill- mapping, job service training and a job search plan. The common feature of Slovak and Finish labour market policy is to foster the better functioning of labour market and to help job seekers to cope better in the labour market. The main goal of employment policy is to foster labour productivity. It resulted in unemployment which has lasted in the Slovak Republic but not in Finland [17].

The main actors in active labour market policies are the Ministry of Employment and the Economy, the Ministry of Social Affairs and Health, the Social Insurence Institution Kela, the Ministry of Education, the municipalities and the Uneployment Funds. The programmes for maintaining of older workers in employment are governed by Ministry of Social Affairs and Health. Each ministry is responsible for specific strategy. Strategy of unemployment of young people is dealt with the Ministry of Education.

Kela is mainly responsible for the income support aspects of labour market programmes. The main goal of Kela and the Unemployment funds is paying unemployment benefits. The unemployment benefits are financed partly by the Unemployment Funds and rest by compulsory national insurence contributions and government funding.

Types of unemployment benefits in Finland [17].

- Labour market support - means - tested, does not require employment history, unlimited period (since 1994)

- Basic unemployment allowance - not means - tested requires a three - year employment history, max. 500 days

- Earnings - based unemployment insurance - not means tested, max 500 benefit (working days)

\subsection{Public expenditure}

In Finland, public expenditure on active and passive labour market programmes totalled $2.48 \%$ of GDP in 2012. The development of the public expenditure on active and passive programmes is permanent. However, public expenditures of the 
Public expenditure on active labour market polices (\% of GDP) in Finland

Table 1

\begin{tabular}{|l|c|c|c|c|c|}
\hline PROGRAMS & $\mathbf{2 0 0 8}$ & $\mathbf{2 0 0 9}$ & $\mathbf{2 0 1 0}$ & $\mathbf{2 0 1 1}$ & $\mathbf{2 0 1 2}$ \\
\hline Public employment services and ADM & 0.15 & 0.17 & 0.18 & 0.17 & 0.16 \\
\hline Training & 0.36 & 0.43 & 0.53 & 0.52 & 0.52 \\
\hline Employment incentives & 0.13 & 0.13 & 0.13 & 0.13 & 0.15 \\
\hline Sheltered and supported employment and rehabilitation & 0.09 & 0.09 & 0.10 & 0.10 & 0.10 \\
\hline Direct job creation & 0.07 & 0.08 & 0.09 & 0.09 & 0.09 \\
\hline Start up incentives & 0.02 & 0.02 & 0.02 & 0.02 & 0.01 \\
\hline Out of work income maintenance & 0.95 & 1.48 & 1.48 & 1.31 & 1.38 \\
\hline Early retirement & 0.39 & 0.40 & 0.31 & 0.17 & 0.07 \\
\hline Total & 2.16 & 2.80 & 2.84 & 2.50 & 2.48 \\
\hline Total active (10-70) & 0.82 & 0.92 & 1.05 & 1.02 & 1.03 \\
\hline Total passive (80-90) & 1.34 & 1.88 & 1.79 & 1.47 & 1.45 \\
\hline
\end{tabular}

Source: [11], own processing

Public expenditure on active labour market polices (\% of GDP) in Slovakia

Table 2

\begin{tabular}{|l|c|c|c|c|c|}
\hline PROGRAMS & $\mathbf{2 0 0 8}$ & $\mathbf{2 0 0 9}$ & $\mathbf{2 0 1 0}$ & $\mathbf{2 0 1 1}$ & $\mathbf{2 0 1 2}$ \\
\hline Public employment services and ADM & 0.11 & 0.10 & 0.10 & 0.07 & 0.07 \\
\hline Training & 0.01 & 0.01 & 0.01 & 0 & 0 \\
\hline Employment incentives & 0.02 & 0.03 & 0.10 & 0.10 & 0.08 \\
\hline Sheltered and supported employment and rehabilitation & 0.02 & 0.03 & 0.03 & 0.04 & 0.05 \\
\hline Direct job creation & 0.05 & 0.01 & 0.01 & 0.01 & 0.01 \\
\hline Start up incentives & 0.06 & 0.07 & 0.08 & 0.07 & 0.05 \\
\hline Out of work income maintenance & 0.11 & 0.29 & 0.24 & 0.25 & 0.26 \\
\hline Early retirement & 0.33 & 0.38 & 0.36 & 0.25 & 0.18 \\
\hline Total & 0.69 & 0.93 & 0.94 & 0.79 & 0.69 \\
\hline Total active (10-70) & 0.26 & 0.25 & 0.33 & 0.30 & 0.25 \\
\hline Total passive (80-90) & 0.43 & 0.67 & 0.61 & 0.50 & 0.44 \\
\hline
\end{tabular}

Source: [11], own processing

Public expenditure on active labour market polices (\% of GDP) in the Czech Republic

Table 3

\begin{tabular}{|l|c|c|c|c|c|}
\hline PROGRAMS & $\mathbf{2 0 0 8}$ & $\mathbf{2 0 0 9}$ & $\mathbf{2 0 1 0}$ & $\mathbf{2 0 1 1}$ & $\mathbf{2 0 1 2}$ \\
\hline Public employment services and ADM & 0.12 & 0.12 & 0.11 & 0.10 & 0.11 \\
\hline Training & 0.01 & 0.03 & 0.04 & 0.01 & 0.01 \\
\hline Employment incentives & 0.01 & 0.02 & 0.05 & 0.04 & 0.02 \\
\hline Sheltered and supported employment and rehabilitation & 0.07 & 0.07 & 0.08 & 0.09 & 0.09 \\
\hline Direct job creation & 0.02 & 0.04 & 0.04 & 0.04 & 0.02 \\
\hline Start up incentives & 0 & 0 & 0 & 0 & 0 \\
\hline Out of work income maintenance & 0.19 & 0.42 & 0.37 & 0.28 & 0.24 \\
\hline Early retirement & 0 & 0 & 0 & 0 & 0 \\
\hline Total & 0.42 & 0.71 & 0.70 & 0.56 & 0.50 \\
\hline Total active (10-70) & 0.23 & 0.29 & 0.33 & 0.27 & 0.26 \\
\hline Total passive (80-90) & 0.19 & 0.42 & 0.37 & 0.28 & 0.24 \\
\hline
\end{tabular}

Source: [11], own processing 
passive policy exceed public expenditures in active policy. The most funded programme is training. This could be a good example for the direction of active labour market policy in Slovakia and the Czech Republic. Education and training contribute to the development of the necessary competencies of people. At the same time it is a mean to achieve a higher degree of satisfaction of workers in the course of their future activities (competence, achievement of performance promotion). Education and development of working skills can be considered as a lifelong process of continuous enhancement and enrichment of the current labour and life knowledge [19] - Table 1.

The structure of the public expenditures is very similar to Slovakia and the Czech Republic. In comparison to Slovakia (Table 2) and the Czech Republic, Finland spends relatively greater proportion of funds on active labour market policy. Paradoxically, Slovakia facing high unemployment spends a greater proportion of the passive labour market policy.

The Czech Republic in comparison with the Slovak Republic and Finland did not expend any financial funds to pay the early retirements in 2008-2012 (Table 3). Funding of passive employment policy to active labour market policy predominates in the Czech Republic and in Slovakia, as well. From these countries, the Slovak Republic expends the biggest amount of funds to pay the passive policy of labour market.

But just active labour market programs can improve the efficiency of job matching by transmitting information on job openings and worker characteristics between employers and jobseekers. They can fill the gap when employers or workers deficiently invest in training because of various market failures, and they can mitigate the impacts of economic downturns by providing workers with temporary employment or creating incentives for employers to hire [20].

\section{Conclusion}

The labour market policy is the complex of the partial policies and at the same time the detailing of methods is necessary. The institutional background in the role of active labour market policy plays the important role. Many times the institutional surroundings cannot adapt to the fast changing conditions of the market. The flexibility of labour market in Slovakia is unsufficient. Apart from the high unemployment in Slovakia, there is also a noticeable problem with the long-term unemployment. The active labour market policy is a tool which opens the possibilities to the new proactive approach of the labour market [21].The important part of labour market policy is training and education. In the consequence of globalization, it is necessary to have at disposal the educated and capable people for labour market. The current labour market requires that students and graduates have interdisciplinary knowledge and skills [22]. If the human resource managers cannot find specialist with required knowledge and skills then is it possible to use popular social networks [23]. Able and motivated people are a decisive source of organization because ability and motivation determines the performance of people and human performance determines the performance of the organization and consequently the whole economy [24]. The investments to the human capital of people present the most profitable form of improving the situation at the labour market from the long-term and perspective point of view. Our country spends relatively little financial resources on active labour market polices, view of the high unemployment rate in Slovakia. This is all the more reason that the established metrics for quantifying and comparing the effectiveness of different measures of the labour market. To increase the efficiency of public resources it is necessary that financial contributions of active labour market policy would focus only in those tools that bring the highest financial and non-financial benefits for our economy in future.

\section{Acknowledgement:}

This article was written as the output of the grant project VEGA $1 / 0421 / 13$

\section{References}

[1] KONUSIKOVA, L.: Approaches to Active Policy on Labour Market in the Slovak Republic and the Czech Republic. Proc. of Intern Scientific Conference Economic Policy in the European Union Members Countries, Ostravice 2014, pp. 485-493. ISBN 978 -807510-045-0

[2] TVRDON, M.: Institutional Frame for the Functioning of Czech Economy upon the Accession to the EU (applied to the labour market). 2007 p. 183. ISBN 978-80-7248-430-0

[3] World Bank. Workers in an Integrating World. World Development Report 1995. Washington: DC: Oxford University Press, 1995.

[4] CAlmfors, L., FORSlund, A., HeMSTROM, M.: Does Active Labour Market Policy Work? Lessons From the Swedish Experiences [online]. IFAU - Institute for Labour Market Policy Evaluation, 2002, [Accessed 29 November 2014]. Available from: http://www.ifau.se/upload/pdf/se/2002/wp02-04.pdf. 
[5] CALMFORS, L.: Active Labour Market Policy and Unemployment - a Framework for the Analysis of Crucial Design Features [online]. OECD Economic Studies, spring 1994, No. 22, pp. 8-47. [Accessed 29 November 2014]. Available from: http://www. oecd.org/social/labour/33936463.pdf.

[6] LAYARD, R., NICKELL, S., JACKMAN, R.: 1992. Unemployment: Macroeconomic Performance at the Labour Market. Oxford University Press.

[7] SIROVATKA, T., KULHAVY, V.: The Evaluation of Efficiency of the Programmes of active Labour Market Policy in the CR. $1^{\text {st }}$ edition, Prague: VUPSV, p. 187 [online]. 2008, [Accessed 29 November 2014]. Available from: http://praha.vupsv.cz/Fulltext/ vz_ 275.pdf.

[8] Central Office of Labour, Social Affairs and Family (Ustredie prace, socialnych veci a rodiny - UPSVaR). Professional and consulting services (Odborne a poradenske sluzby) Policies [online]. 2014, [Accessed 29 November 2014]. Available from: http:// www.upsvar.sk/sluzby.

[9] FRASER, N.: How Strong is the Case for Targeting Active Labour Market Policies? Intern. J. of Manpower [online]. 1999, [Accessed 29 November 2014]. Available from: http://www.emeraldinsight.com/doi/abs/10.1108/01437729910279081.

[10] JACKMAN, R. et al.: Combating Unemployment, Is flexibility enough Centre for Economic Performance, London School of Economics and Political Science, 1996.

[11] Organization for Economic Co-operation and Development (OECD). Public expenditure of \% as a percentage of GDP [online]. Statistical database, 2014, [Accessed 29 November 2014]. Available from: http://stats.oecd.org/.

[12] Europa.eu. Active Labour Market Policies [online]. 2014, [Accessed 29 November 2014]. Available from: http://ec.europa.eu/ europe2020/pdf/themes/24_almp_and_employment_services.pdf.

[13] SCARPETTA, S.: Assessing the Role of Labour Market Policies and Institutional Settings on Unemployment. OECD Economic Studies, 1/1996, No. 26, pp. 44-98.

[14] KLUVE, J.: The Effectiveness of European Active Labour Market Policy [online]. RWI Discussion Papers, 2006, No. 37. [Accessed 29 November 2014]. Available from: https://www.econstor.eu/dspace/bitstream/10419/18588/1/DP_06_037.pdf.

[15] Integrated Portal. Active Employment Policy and Law no. 435/2004 Sb., about Employment [online]. 2014, [Accessed 28 November 2014]. Available from: http://portal.mpsv.cz/sz/zamest/dotace/apz

[16] HEIKKI, R. et al.: Labour Market Reforms and Performance in Denmark, Germany, Sweden and Finland Publications of the Ministry of Employment and the economy [online]. Publications of the Ministry of Employment and the Economy, Employment and Entrepreneurship 19/2012, 2012, [Accessed 29 November 2014]. Available from: https://www.tem.fi/files/32993/ TEMjul_19_2012.web.pdf

[17] OECD. 2014 Activtion Policies in Finland [online]. 2015, [Accessed 22 March 2015]. Available from: http://www.oecd-ilibrary. org/social-issues-migration-health/activation-policies-in-finland_220568650308

[18] KONUSIKOVA, L.: Approaches to Active Policy on Labour Markets in Slovakia and Finland 2014, Intern. scientific conference of PhD students and young researchers 2014. Karvina : Silesian University in Opava : School of Business Administration in Karvina, pp. 155-162. ISBN 978-80-7248-836-0

[19] KUCHARCIKOVA, A.: The Importance of Identification and Analysis of Educational Needs for Investment in Human Capital. Communications - Scientific Letters of the University of Zilina, vol. 16, No. 3/2014, pp. 86-92, ISSN 1335-4205

[20] World Development Report 2013 Jobs, The World Bank. [Accessed 25 March 2015]. Available from: http://siteresources. worldbank.org/EXTNWDR2013/Resources/ 8258024-1320950747192/8260293-1322665883147/WDR_2013_Report.pdf

[21] KUCHARCIKOVA, A.: Macroeconomics. EDIS, University of Zilina, 2009, 236 p. ISBN 978-80-8070-978-5

[22] DURISOVA, M.: Modern Methodological Approach to Teaching Business Economics for IT Students. Procedia - Social and Behavioral Sciences [online], 2013, vol. 106, 1850-1856

[23] TOKARCIKOVA, E.: Influence of Social Networking for Enterprise's Activities. Periodica Polytechnica, Social Management Sciences 19/1, 2011, 37-41, 2011

[24] SIKYR, M.: The Best Practices in Human Resource Management. Grada Publishing: Prague, 2014, p. 200, ISBN 978-80-247-5212-9. 